\title{
Photochemically-Activated Probes of Protein-Protein
}

\section{Interactions}

\author{
Sandip K. Nandy, Richard S. Agnes, and David S. Lawrence*
}

Department of Biochemistry

The Albert Einstein College of Medicine

1300 Morris Park Ave

Bronx, NY 10461

\section{Supporting Information}

\section{EXPERIMENTAL PROCEDURES}

Materials and chemicals were obtained from Fisher and Aldrich, unless otherwise indicated. 1-hydroxybenzotriazole (HOBt), benzotriazole-1yloxytrispyrrolidinophosphonium hexa-fluorophosphate (PyBop), $N, N_{,} N_{-}, N_{-}-$ tetramethyl-O-(6-chloro-1 $\mathrm{H}$-benzotriazol-1-yl)uronium hexafluorophosphate (HCTU), $\overline{6}$ chloro-1-hydroxybenzotriazole dehydrate, (HOBt-Cl) $\mathrm{N}$-[(dimethylamino)-1H-1,2,3triazolo[4,5 (HATU), 1-hydroxy-7-azabenzotriazole (HOAt), protected amino acids, and CLEAR Rink amide resin (100-200 mesh, $0.43 \mathrm{mmol} / \mathrm{gram})$ were obtained from Advanced ChemTech, Bachem, Novabiochem, or Peptides International. $\mathrm{Pd}\left(\mathrm{PPh}_{3}\right)_{4}$ was obtained from Strem Chemicals. Dapoxyl sulfonyl chloride was obtained from Invitrogen. P-81 cellulose UNIFILTER plates were obtained from Whatman. GST-Lck-SH2 and PKA catalytic subunit plasmids were gifts from Dr. Qunzhao Wang and Dr. Hsien-Ming Lee, respectively. Fluorescence assays were performed using a Photon Technology QM-1 spectrofluorimeter, and irradiation experiments utilized an Oriel Mercury Arc Lamp (Model 69907) equipped with a $360 \mathrm{~nm}$ colored glass filter (300 - $400 \mathrm{~nm}$ band pass) and an IR filter. 


\section{Peptides Synthesis}

All peptides were manually synthesized using a standard Fmoc solid-phase peptide synthesis protocol. The side chains of Glu and Ser were protected with $\mathrm{O}-\mathrm{t}$-Bu. The side chain of Arg was protected with the $N^{\omega}$-(2,2,4,6,7-pentamethyldihydrobenzofuran-5sulfonyl (Pbf) group. The side chain group of phosphotyrosine was protected with $O$ benzyl. The side chain amine of (L)-2,3-diaminobutyric acid (Dab) residue was protected with the allyloxycarbonyl (Alloc) group.

Ac-pTyr- $N(D M N B) G l y-G l u-l l e-D a b(A c)-A l a-N_{2}(4) \quad \mathrm{C}_{42} \mathrm{H}_{60} \mathrm{~N}_{9} \mathrm{O}_{18} \mathrm{P}$, mass calcd $\mathrm{m} / \mathrm{z}$ 1009.38, obsd 1009.66 (M+); Ac- $N^{\alpha}(\mathrm{DMNB})$ pTyr-Gly-Glu-lle-Dab(Ac)-Ala-NH $\mathrm{NH}_{2}$ (5) $\mathrm{C}_{42} \mathrm{H}_{60} \mathrm{~N}_{9} \mathrm{O}_{18} \mathrm{P}$, mass calcd m/z: 1009.38, obsd: 1007.62 (M-2); Ac-pTyr-Gly-Glu-lle$\mathrm{Dab}(\mathrm{Ac})-\mathrm{Ala}-\mathrm{NH}_{2}(6) \mathrm{C}_{33} \mathrm{H}_{51} \mathrm{~N}_{8} \mathrm{O}_{14} \mathrm{P}$, mass calcd $\mathrm{m} / \mathrm{z}$ 814.33, obsd 812.05 (M-2); Ac-GlyGly-Gly-Phe-coumarin (7) $\mathrm{C}_{29} \mathrm{H}_{32} \mathrm{~N}_{6} \mathrm{O}_{8}$, mass calcd $\mathrm{m} / \mathrm{z}$ : 592.23 , obsd: $593.86(\mathrm{M}+1)$; Ac-Gly-Gly-Gly- $N(D M N B)$ Phe-coumarin (8) $\mathrm{C}_{38} \mathrm{H}_{41} \mathrm{~N}_{7} \mathrm{O}_{12}$, mass calcd $\mathrm{m} / \mathrm{z} 787.28$, obsd $788.36(\mathrm{M}+1) ; \quad \mathrm{H}_{2} \mathrm{~N}$-Leu-Arg-Arg-Ala-Ser-Leu-Gly- $\mathrm{NH}_{2}(9)$ previously described (Mendelow, M.; Prorok, M.; Salerno, A.; Lawrence, D. S. J. Biol. Chem., 1993, 268, 12289-96); $\mathrm{H}_{2} \mathrm{~N}$-Leu-Arg-Arg-Ala- $N(\mathrm{DMNB})$ Ser-Leu-Gly-NH $\mathrm{N}_{2}(\mathbf{1} 0) \mathrm{C}_{41} \mathrm{H}_{71} \mathrm{~N}_{15} \mathrm{O}_{12}$, mass calcd $\mathrm{m} / \mathrm{z}$ 966.10, obsd 968.40 (M+2); Ac-pTyr-Gly-Glu-Ile-Dab(Dapoxyl)-Ala-NH $\mathrm{N}_{2}$ (11) $\mathrm{C}_{48} \mathrm{H}_{63} \mathrm{~N}_{10} \mathrm{O}_{16} \mathrm{P}$, mass calcd $\mathrm{m} / \mathrm{z}$ 1098.39, obsd $1097.03(\mathrm{M}-1)$.

Each amino acid was attached via a standard addition/deprotection stepwise protocol [steps (a) and (b)]. The reductive alkylation procedure (c) and coupling of the subsequent Fmoc-residue (d) were performed under the specified conditions, as was the coupling of the amino acid immediately following lle in peptides $4-6$ (e). Side chain deprotection of specific residues for subsequent modification (to furnish peptides $\mathbf{4 - 6}$, 11 ) is described in (f). Peptides were cleaved from the solid support as outlined in (g).

(a) Addition of standard Fmoc-amino acids to peptide chain: three equivalents of the Fmoc-protected amino acid, PyBOP, HOBt hydrate, and six equivalents of $\mathrm{N}$ methylmorpholine (NMM) in DMF (3 hr).

(b) Deprotection of Fmoc group on the growing peptide chain: (i) $1 \times 15 \mathrm{~mL}$ of $30 \%$ piperidine in DMF (30 min) (ii) $3 \times 15 \mathrm{~mL}$ of DMF, (iii) $3 \times 15 \mathrm{~mL}$ of isopropyl alcohol, (iv) $3 \times 15 \mathrm{~mL}$ of $\mathrm{CH}_{2} \mathrm{Cl}_{2}$.

(c) Reductive alkylation procedure for the incorporation of the DMNB caging group onto the peptide chain: the free primary amine peptide-resin $(500 \mathrm{mg})$ was washed $\mathrm{DMF} / \mathrm{MeOH} / \mathrm{AcOH}$ (9:9:2) drained and then mixed with 3 equiv of 4,5-dimethoxy-6nitrobenzaldehyde (DMNB) in $10 \mathrm{~mL}$ of DMF/MeOH (1:1) for $40 \mathrm{~min}$. The solvent was then removed and the imine-forming reaction repeated. Following solvent removal, the resin was washed with $10 \mathrm{~mL}$ of DMF twice, and then 5 equiv of $\mathrm{NaBH}_{3} \mathrm{CN}$ in $\mathrm{DMF} / \mathrm{MeOH} / \mathrm{AcOH}$ (9:9:2) was added to the resin and mixed at room temperature for 20 min. The solvent was removed and the resin successively washed with DMF, DMF/ $\mathrm{H}_{2} \mathrm{O}$, $\mathrm{H}_{2} \mathrm{O}, \mathrm{MeOH} / \mathrm{CH}_{2} \mathrm{Cl}_{2}, \mathrm{CH}_{2} \mathrm{Cl}_{2}$, and DMF. The reaction was monitored by HPLC and ESI$\mathrm{MS}$ analyses of cleaved product from a few $\mathrm{mg}$ of resin with $97 \%$ aqueous TFA. The reaction and the subsequent peptide synthesis were performed in reaction vessels that were wrapped in aluminum foil. 

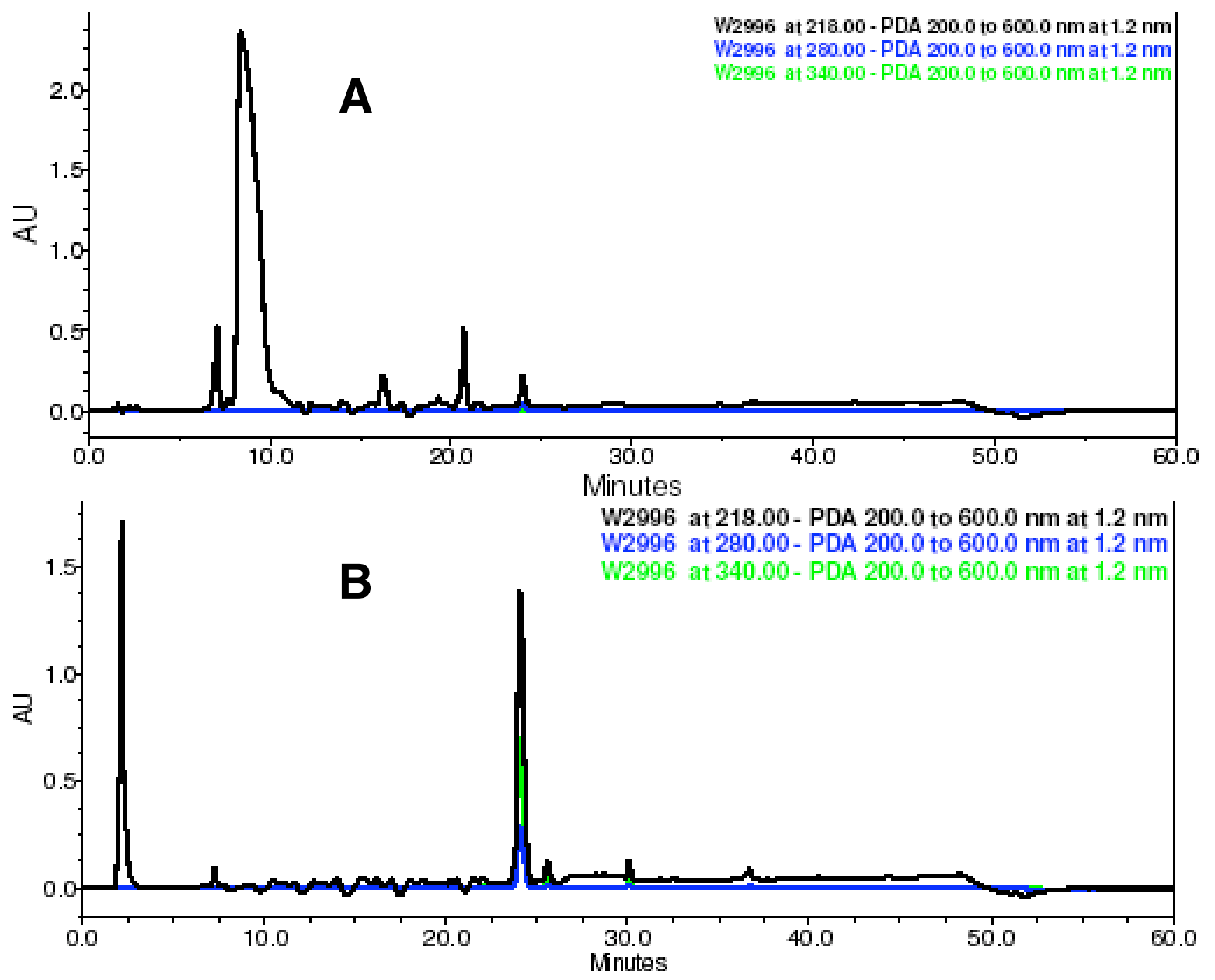

Figure S-1. Monitoring at 218 (black), 280 (blue) and 340 (green) $\mathrm{nm}$ of the reductive alkylation reaction by cleaving sample resins with $97 \%$ TFA. HPLC chromatogram of cleaved products before $(\mathbf{A})$ and after $(\mathbf{B})$ reductive alkylation of the Ser-Leu-Gly-resin in $20 \mathrm{~min}\left[0-50 \% \mathrm{CH}_{3} \mathrm{CN}\right.$ over $45 \mathrm{~min}$ on an Apollo $\mathrm{C} 18(4.6 \mathrm{~mm} \times 250 \mathrm{~mm})$ analytical column].

(d) Amino acid coupling to the resin N-DMNB peptide: Peptides 5 and 8: A solution of 6 equiv of the Fmoc-protected amino acid, HATU, and 18 equiv of DIPEA (diisopropylethylamine) in DMF was preactivated for $1 \mathrm{~min}$. The solution was added to the resin-bound $N$-DMNB peptide and shaken for $2 \mathrm{hr}$. Peptide 10: The acid chloride of Fmoc-Ala was prepared using a standard protocol (Carpino, L.A.; Cohen, B.J.; Stephens Jr., K.E.; Sadat-Aalaee, Y.; Tien, J.-H.; Langridge, D.C. J. Org. Chem., 1986, 51, 3732-34). Briefly, the Fmoc-amino acid was dried over phosphorus pentoxide in a desiccator overnight. A $250 \mathrm{~mL}$ round bottom flask was charged with $3.2 \mathrm{mmol}$ of 
Fmoc-Ala. $2.5 \mathrm{~mL}$ of $\mathrm{SOCl}_{2}$ (ca. $32 \mathrm{mmol}$ ) was added via a cannula along with $23 \mu \mathrm{L}$ of anhydrous DMF. The clear mixture was stirred for $1 \mathrm{~h}$ at room temperature. Excess $\mathrm{SOCl}_{2}$ was evaporated. The acid chloride of Fmoc-Ala was crystallized by addition of 5 $\mathrm{mL}$ cold $\mathrm{CH}_{2} \mathrm{Cl}_{2}$ followed by $50 \mathrm{~mL}$ hexane. The crystals were filtered and dried over vacuum for $1 \mathrm{~h}$. After washing thoroughly with more THF, 20 equiv. of freshly prepared Fmoc-Ala-Cl in THF (5 mL/1 g resin - previously swelled in THF for $1 \mathrm{~h}$ ) was added and shaken for $30 \mathrm{~min}$. 40 equiv. of DIPEA was subsequently added and the mixture allowed to react for an additional $2 \mathrm{~h}$. The extent of racemization was determined by synthesizing the peptide containing the corresponding Fmoc- $D$-amino acid (i.e. Leu-ArgArg-D-Ala-N(DMNB)-Ser-Leu-Gly-amide) and comparing its retention times with that of the desired L-Ala derivative (Leu-Arg-Arg-L-Ala-N(DMNB)-Ser-Leu-Gly-amide). No significant racemization was detected using this coupling protocol.
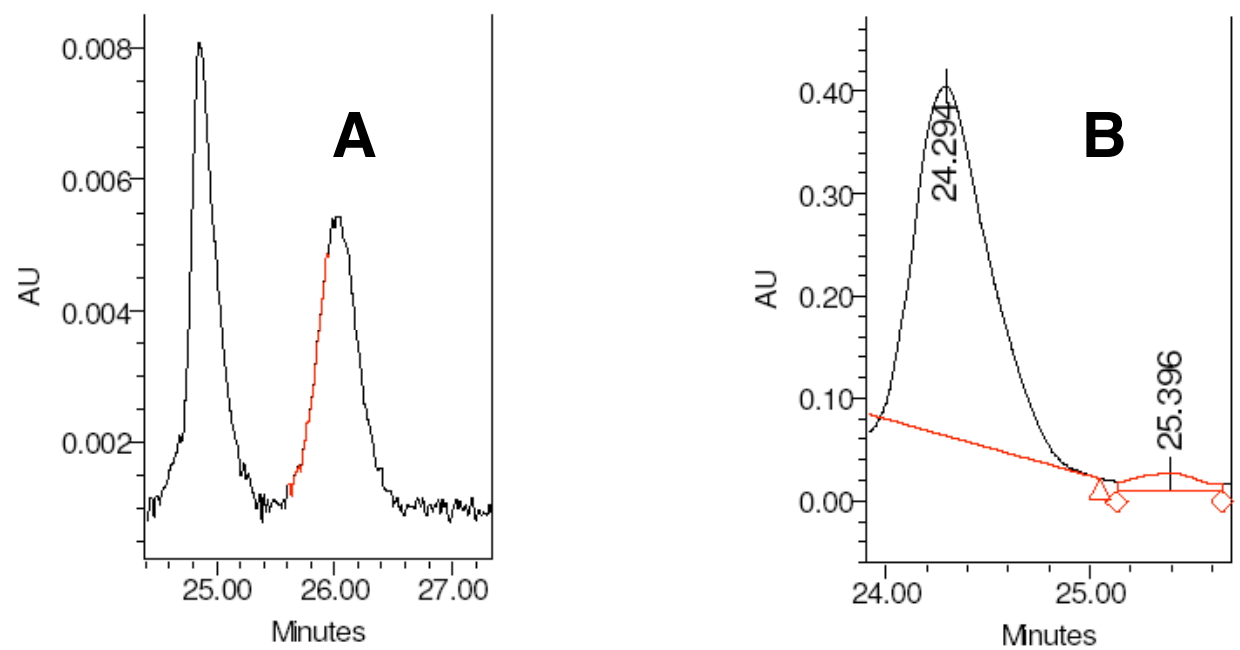

Figure S-2. An HPLC chromatogram of independently synthesized and co-injected LeuArg-Arg-L-Ala-N(DMNB)-Ser-Leu-Gly-amide ( $1^{\text {st }}$ peak) and Leu-Arg-Arg-D-Ala$\mathrm{N}(\mathrm{DMNB})$-Ser-Leu-Gly-amide $\left(2^{\text {nd }}\right.$ peak $)(\mathbf{A})$. The peptides were resolved with an analytical column [Apollo C18 $(4.6 \mathrm{~mm} \times 250 \mathrm{~mm})$ ] using a slow gradient of $0-50 \%$ $\mathrm{CH}_{3} \mathrm{CN}$ over $45 \mathrm{~min}$. We observe approximately $4 \%$ racemization upon coupling of the acid chloride of Fmoc-L-Ala (B).

(e) Coupling of the amino acid immediately after lle $(4,5,6)$ was effected via initial exposure to the standard coupling conditions (i.e. with PyBop and HOBt), followed by a subsequent treatment with the amino acid to be coupled in the presence of HATU and HOAt.

(f) Following coupling of all the amino acids, the Dab side chain protected peptide-resin was treated with freshly prepared solution of $\mathrm{Pd}\left(\mathrm{PPh}_{3}\right)_{4}$ (1 equiv relative to resin substitution) in $\mathrm{CH}_{2} \mathrm{Cl}_{2} / \mathrm{HOAc} / \mathrm{NMM}(48: 1: 1)$ to selectively remove the Alloc protecting group and expose the side chain Dab amine moiety. The resins were subsequently washed with $0.5 \%$ DIPEA followed by $0.5 \%$ sodium diethyldithiocarbamate in DMF. The peptide was then treated with acetic anhydride (4 equiv) and DIPEA (8 equiv) (4, $\mathbf{5}$, 
6) in dry $\mathrm{CH}_{2} \mathrm{Cl}_{2}$ and allowed to react overnight. Peptide 11 has been previously described (Wang, Q.; Lawrence, D. S. J. Amer. Chem. Soc., 2005, 127, 7684-5).

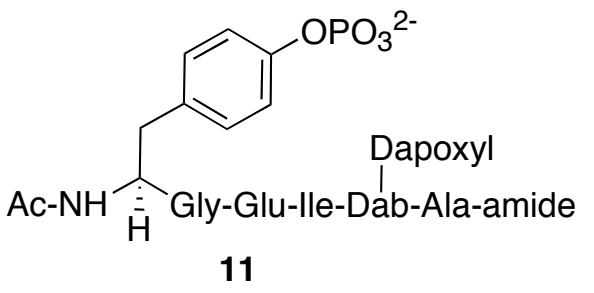

(g) Peptides were cleaved from the resin (95\% TFA, 2.5\% triisopropylsilane, $2.5 \% \mathrm{H}_{2} \mathrm{O}$ ), and purified by preparative reverse phase HPLC (Waters Atlantis dC18 $19 \mathrm{~mm} \mathrm{X} 100$ $\mathrm{mm}$ ) using a binary solvent system (solvent $A$ : $0.1 \% \quad T F A / H_{2} \mathrm{O}$; solvent $B: 0.1 \%$ TFA/CH ${ }_{3} \mathrm{CN}$ ) with a ratio of (solvent A):(solvent $B$ ) that varied from 97:3 (0 min) to 75:25 (5 min) and then changed in a linear fashion to 65:35 (75 min).

\section{Preparation of the Fmoc-coumarin derivative 13.}<smiles>Cc1c(C(=O)O)c(=O)oc2cc(N)ccc12</smiles>

12<smiles>Cc1c(C(=O)O)c(=O)oc2cc(NOCF)ccc12</smiles>

13

The free amine 12 was protected as the Fmoc derivative using a standard protocol (Backes, B. J.; Harris, J. L.; Leonetti, F.; Craik, C. S.; Ellman, J. A. Nat. Biotechnol. 2000 18, 187-93). ${ }^{1} \mathrm{H}$ NMR (DMSO): d 10.22 (s, 1H), 7.91-7.93 (d, $J=7.2 \mathrm{~Hz}, 2 \mathrm{H}$ ), 7.73$7.78(\mathrm{~m}, 3 \mathrm{H}), 7.55(\mathrm{~s}, 1 \mathrm{H}), 7.34-7.46(\mathrm{~m}, 5 \mathrm{H}), 4.55-4.57(\mathrm{~d}, J=6.6 \mathrm{~Hz}, 2 \mathrm{H}), 4.32-4.36(\mathrm{t}$, $J=6.6 \mathrm{~Hz}, 1 \mathrm{H}), 3.58(\mathrm{~s}, 2 \mathrm{H}), 2.36(\mathrm{~s}, 3 \mathrm{H})$. Derivative 13 was directly coupled to the Rink resin as described above in (a).

\section{$K_{\mathrm{d}}$ determinations of $\mathrm{SH} 2$ domain peptides}

Experiments were conducted with $3 \mu \mathrm{M}$ of peptide 11 sensor, $20 \mu \mathrm{M}$ DTT, varied concentrations of GST-Lck-SH2 (in 10\% glycerol) in $33.3 \mathrm{mM}$ Tris buffer (pH 7.5) in an assay volume of $150 \mu \mathrm{L}$. The fluorescence of the solution was monitored on a Photon Technology QM-1 spectrofluorimeter at $30^{\circ} \mathrm{C}$ at $\lambda_{\mathrm{ex}}=395 \mathrm{~nm}$ and $\lambda_{\mathrm{em}}=535 \mathrm{~nm}$. The fluorescence of the peptide solution was measured with variable concentration of GSTLck-SH2 $(0.1 \mu \mathrm{M}, 0.2 \mu \mathrm{M}, 0.4 \mu \mathrm{M}, 0.8 \mu \mathrm{M}, 1.6 \mu \mathrm{M}, 3.2 \mu \mathrm{M}, 6.4 \mu \mathrm{M}, 12.8 \mu \mathrm{M}, 25.6 \mu \mathrm{M})$. Control assays in the absence of GST-Lck-SH2 were also performed at the same concentrations. The $K_{d}(1.5 \pm 0.3)$ for the sensor peptide 11 was determined using the following equations.

$$
K_{\mathrm{d}}=\frac{\left(\left[\mathrm{S}_{\mathrm{T}}\right]-[\mathrm{SP}]\right)\left(\left[\mathrm{P}_{\mathrm{T}}\right]-[\mathrm{SP}]\right.}{[\mathrm{SP}]}
$$

where 


$$
[\mathrm{SP}]=\frac{\left(\mathrm{F}_{\mathrm{x}}-\mathrm{F}_{\mathrm{o}}\right)}{\left(\mathrm{F}_{\max }-\mathrm{F}_{\mathrm{o}}\right)}\left[\mathrm{S}_{\mathrm{T}}\right]
$$

and $\left[S_{t}\right]=$ total $[11], F_{x}=$ fluorescence at specific $\left[\right.$ Lck-SH2], $F_{\max }=$ maximum fluorescence at excess [Lck-SH2], $F_{0}=$ starting fluorescence where $[\mathrm{Lck}-\mathrm{SH} 2]=0,\left[\mathrm{P}_{\mathrm{t}}\right]=$ total $[$ Lck-SH2], [SP] $=[11 /$ Lck-SH2].

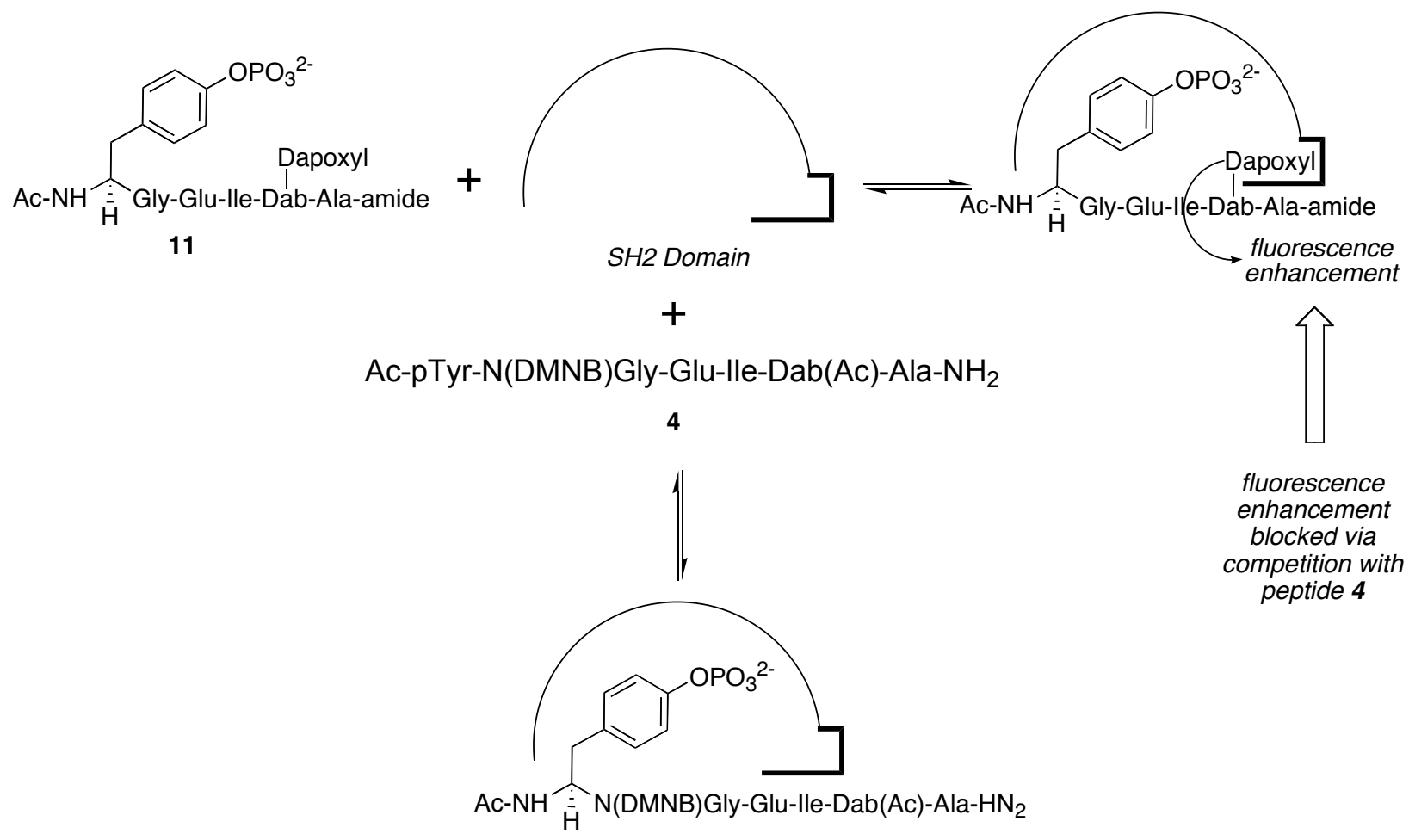

Scheme S-1. Competition assay to assess the $K_{d}$ values of peptides $4-6$.

Subsequent $K_{d}$ determinations for caged $\mathrm{SH} 2$ domain peptides 4 and $\mathbf{5}$, and noncaged derivative 6 were performed via competition with peptide $11(3 \mu \mathrm{M})$ in $20 \mu \mathrm{M}$ DTT, $5 \mu \mathrm{M}$ GST-Lck-SH2 (in 10\% glycerol), and $33.3 \mathrm{mM}$ of Tris buffer (pH 7.5) in a total assay volume of $150 \mu \mathrm{L}$. The fluorescence of the solution was monitored on a Photon Technology QM-1 spectrofluorimeter at $30^{\circ} \mathrm{C}$ at $\lambda_{\mathrm{ex}}=395 \mathrm{~nm}$ and $\lambda_{\mathrm{em}}=535$ $\mathrm{nm}$. The fluorescence of the peptide 11 solution was measured in the presence of variable concentrations of peptides 4,5 , or $\mathbf{6}$. Control assays in the absence of GSTLck-SH2 were also performed at the same concentrations. The following $K_{\mathrm{dx}}$ values were obtained: peptide $4(127 \pm 6 \mu \mathrm{M})$, peptide $5(43 \pm 10 \mu \mathrm{M})$, and peptide $6(2.6 \pm$ $0.2)$.

$$
K_{\mathrm{dx}}=\frac{[\mathrm{P}]\left(\left[\mathrm{X}_{\mathrm{T}}\right]-[\mathrm{XP}]\right)}{[\mathrm{XP}]}
$$

where 


$$
\begin{gathered}
{[\mathrm{P}]=\frac{K_{\mathrm{d}}[\mathrm{SP}]}{\left[\mathrm{S}_{\mathrm{T}}\right]-[\mathrm{SP}]}} \\
{[\mathrm{XP}]=\left[\mathrm{P}_{\mathrm{T}}\right]-[\mathrm{P}]-[\mathrm{SP}]} \\
{[\mathrm{SP}]=\frac{\left(\mathrm{F}_{\mathrm{x}}-\mathrm{F}_{\mathrm{o}}\right)}{\left(\mathrm{F}_{\max }-\mathrm{F}_{\mathrm{o}}\right)}\left[\mathrm{S}_{\mathrm{T}}\right]}
\end{gathered}
$$

and $\left[S_{t}\right]=$ total [11], $F_{X}=$ fluorescence at a given concentration of peptide $X$ (i.e. 4, 5, or 6), $F_{\max }=$ fluorescence in the absence of peptide $X, F_{0}=$ fluorescence in the absence of Lck-SH2 domain, $K_{d}=$ binding constant of 11/Lck-SH2 domain, $\left[\mathrm{P}_{\mathrm{t}}\right]=$ total [Lck-SH2], [P] $=$ uncomplexed $\left[\right.$ Lck-SH2], $\left[\mathrm{X}_{\mathrm{t}}\right]=$ total $[4,5$, or $\mathbf{6}],[\mathrm{PX}]=[\mathbf{4}, \mathbf{5}$, or 6/Lck-SH2 complex], $[S P]=[11 /$ Lck-SH2 complex $], K_{d x}=$ dissociation constant of peptide 4,5 , or $6 /$ Lck-SH2 domain complex.

\section{Photolysis of caged peptides}

Peptides 4 and 5: experiments were conducted using $3 \mu \mathrm{M}$ peptide 11, $20 \mu \mathrm{M}$ DTT, 5 $\mu \mathrm{M}$ GST-Lck-SH2 (in 10\% glycerol), the caged peptide 4 or $5(32 \mu \mathrm{M})$ in $33.3 \mathrm{mM}$ Tris buffer $(\mathrm{pH} 7.5)$ and a total assay volume $150 \mu \mathrm{L}$ [quartz cuvette; lightpath $(10 \mathrm{~mm})$ width $(10 \mathrm{~mm})]$. The fluorescence of the solution was monitored on a Photon Technology QM1 spectrofluorimeter at $30^{\circ} \mathrm{C}$ at $\lambda_{\text {ex }}=395 \mathrm{~nm}$ and $\lambda_{\text {em }}=535 \mathrm{~nm}$. Caged peptide (4) was irradiated using an Oriel Mercury Arc Lamp (Model 69907) equipped with a $360 \mathrm{~nm}$ colored glass filter (300 - $400 \mathrm{~nm}$ band pass) and an IR filter for various time periods ( 0 $-30 \mathrm{~min}$ ). An aliquot from each irradiation time period was added to the assay solution. A decrease in fluorescence intensity is indicative of displacement of the $\mathrm{SH} 2$ domain sensor 11 from the $\mathrm{SH} 2$ domain by photouncaged peptide (i.e. formation of $\mathbf{6}$ ). The formation of uncaged peptide 6 from caged peptides 4 and 5 was confirmed by analytical HPLC (comparison with the retention time of peptide 6 prepared by solid phase peptide synthesis) and by mass spectrometry. Peptide $8(25 \mu \mathrm{M})$ was irradiated as described above $(0,5,10,15$, and 20 min exposure times) in $50 \mathrm{mM}$ Tris buffer $(\mathrm{pH}$ 8.0 ), and $100 \mathrm{mM} \mathrm{NaCl}, 5 \mathrm{mM} \mathrm{CaCl}$, and $0.01 \%$ Tween-20. Irradiated material was subsequently exposed to $\alpha$-chymotrypsin (vide infra). Peptide $10(30 \mu \mathrm{M})$ was photolyzed (vide supra) for different time periods (5, 10, 15, 20, 25, $30 \mathrm{~min}$ ) and then subjected to PKA (vide infra). 


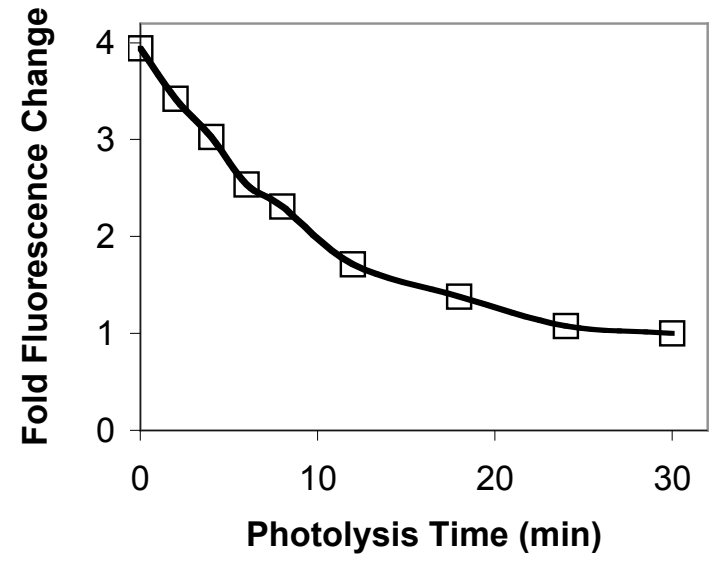

Fig. S-3. Fluorescence change as a function of photolysis time of caged peptide 4. At $\mathrm{t}=0 \mathrm{~min}$, the dapoxyl peptide $\mathbf{1 1}$ is completely bound to the Lck-SH2 domain and exhibits a 4-fold enhancement in fluorescence intensity relative to 11 in the absence of Lck-SH2 domain. Increasing irradiation times converts increasing quantities of $\mathbf{4}$ to active peptide 6 resulting ultimately in the complete displacement of $\mathbf{1 1}$ from the Lck $\mathrm{SH} 2$ domain.

\section{Chymotrypsin Assay and Determination of $K_{\mathrm{m}}$ and $V_{\max }$ values with peptide 7} Assays were performed in triplicate using peptide 7 concentrations that varied about the $K_{\mathrm{m}}(0.39 \mu \mathrm{M}, 0.78 \mu \mathrm{M}, 1.56 \mu \mathrm{M}, 3.12 \mu \mathrm{M}, 6.25 \mu \mathrm{M}, 12.5 \mu \mathrm{M}, 25 \mu \mathrm{M})$ in $50 \mathrm{mM}$ Tris buffer (pH 8.0), $100 \mathrm{mM} \mathrm{NaCl}, 5 \mathrm{mM} \mathrm{CaCl}_{2}, 10 \mathrm{nM} \alpha$-chymotrypsin, and $0.01 \%$ Tween20. The peptide 7 stock solution contained $5 \%$ DMSO and the assay solution contained less than $1 \%$ DMSO. The reaction was monitored on a Photon Technology QM-1 spectrofluorimeter at $30^{\circ} \mathrm{C}$ using a $\lambda_{\mathrm{ex}}=380 \mathrm{~nm}$ and $\mathrm{a} \lambda_{\mathrm{em}}=460 \mathrm{~nm}$.

\section{Radioactive assay of the photolyzed PKA peptide 10}

PKA assays were performed in triplicate. $20 \mu \mathrm{L}$ of a photolyzed $30 \mu \mathrm{M}$ solution of 10 was added to each well of 96 multi-well assay plate containing $20 \mu \mathrm{L}$ assay buffer [100 $\mathrm{mM}$ MOPS, $150 \mathrm{mM} \mathrm{KCl}, 12.5 \mathrm{mM} \mathrm{MgCl}_{2}$ and $150 \mu \mathrm{M}$ cold ATP supplemented with 70 $163 \mu \mathrm{Ci} /$ well $\left[\gamma^{-33} \mathrm{P}\right.$ ]ATP for radioactive detection]. $10 \mu \mathrm{L}$ enzyme diluted buffer containing $100 \mathrm{mM}$ MOPS (pH 7.1), $0.125 \mathrm{mg} / \mathrm{mL}$ bovine serum albumin, and $8 \mathrm{nM}$ PKA catalytic subunit were added to initiate the reaction. Total reaction volume was 50 $\mu \mathrm{L}$. After a $12 \mathrm{~min}$ incubation time at $30^{\circ} \mathrm{C}, 100 \mu \mathrm{L}$ of $6 \%$ phosphoric acid was added to each well to stop the reaction (total volume: $150 \mu \mathrm{L}$ ). Following an additional 5 min incubation period at ambient temperature, $75 \mu \mathrm{L}$ from each reaction well was transferred into each well of a UNIFILTER (P81 cellulose phosphate paper) assay plate. Each well was washed four times with $0.1 \%$ phosphoric acid in water. Scintillation solution was added to each well and ${ }^{33} \mathrm{P}$-incorporation measured by scintillation counting with a MicroBeta ${ }^{\text {TM }}$ TriLux \& MicroBeta JET (Perkin Elmer). The formation of the photouncaged peptide was confirmed by ESI mass spectrometry. A time-based PKA assay with photolyzed peptide $\mathbf{1 0}$ was performed as described above except that the enzymatic reaction was stopped at different time points $(2,4,6,8,10,12,14 \mathrm{~min})$ by adding $6 \%$ phosphoric acid. 